\title{
Parameters for simulation of the thermal state and fire-resistant quality of hollow-core floors used in the mining industry
}

\author{
Andrii Kovalov ${ }^{1 *}$, Volodymyr Konoval ${ }^{3}$, Anastasiia Khmyrova $^{2}$, and Kateryna Dudko ${ }^{3}$ \\ ${ }^{1}$ Cherkasy Institute of Fire Safety of National University of Civil Defence of Ukraine, 8 Onopriienko \\ Ave., 18034 Cherkasy, Ukraine \\ ${ }^{2}$ National University of Civil Defence of Ukraine, 94 Chernyshevska St., 61023 Kharkiv, Ukraine \\ ${ }^{3}$ Cherkasy State Technological University, 460 Shevchenka Ave., 18006 Cherkasy, Ukraine
}

\begin{abstract}
The statistical data of the fire and technogenic safety in Ukrainian mines have been studied. A literary analysis has been made of advanced expertise in determining the fire resistance of building structures. It has been studied the thermal state and fire resistance of hollow-core floors using the fire tests and the calculated determination of the fire resistance degree of a structure based on a two-dimensional model of thermal conductivity and convective heat transfer implemented in the ANSYS R17.1 software complex. The fire test of hollow-core floor has been analysed and the use of a computational-experimental method is proposed to determine the parameters when simulating the thermal state and the fire resistance of both protected and unprotected hollow-core floors. A technique has been developed for simulating the thermal state and the fire resistance of hollow-core floors, which can be used in assessment of the fire resistance degree of reinforced concrete building structures both in industrial construction and in the mining industry.
\end{abstract}

\section{Introduction}

For 4 months of 2019, there were 8 fires in the enterprises of the fuel and energy complex of Ukraine, of which 5 fires occurred in the mines, namely: one after another fires occurred at VP Heroiv Kosmosu mine, PJSC "DTEK Pavlohradvuhillia", VP "Kotliarevska" Mine PJSC "DTEK Pavlohradvuhillia", VP "Pivnichna" mine DP "Toretskvuhillia PSPVPU", PJSC Colliery Group Pokrovske and at VP " $1 / 3$ Novohrodivska" mine DP "Selydivvuhillia". The general damages from these fires amounted to $52298000 \mathrm{UAH}$, of them the expenses for of emergency-rescue operations amounted to $15023800 \mathrm{UAH}$. That is, at the mining industry facilities there is a technogenic and fire hazard that can constitute a threat to the environment, people's lives and lead to the emergence of technogenic situations [1 - 7].

Among the building structures used both in modern construction [8-10], and in the construction and strengthening of mines, the hollow-core floor slabs of various types are commonly used (Fig. 1).

\footnotetext{
*Corresponding author: kovalev27051980@gmail.com
} 


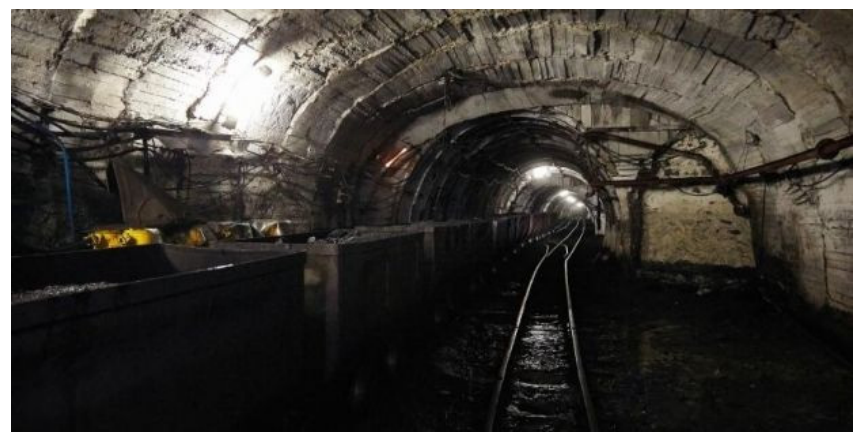

Fig. 1. The use of concrete floor slabs at the mining industry facilities.

Since these armoured concrete structures often do not meet the fire safety requirements in terms of normalized values of their fire resistance degree, it was and is relevant to ensure and improve the fire resistance of such structures by fire protection with the use of various substances and materials. When designing the fire protection of such structures, there is an acute problem of accurate calculating the thermal state of both protected and unprotected hollow-core floors, which is largely determined by the accuracy of setting model parameters that ensure its adequacy to actual heat exchange processes when testing for fire resistance. Such parameters include the thermal conductivity coefficient, the specific volumetric heat capacity of both concrete and fire-retardant coating, as well as test conditions (number of samples, the value of the average volumetric temperature and humidity in the test chamber), which must be ensured during the process of determining the effectiveness of these coatings.

Among the model parameters, it is necessary to identify those that are unknown, insufficiently known and influence significantly on the calculated temperature values of the selected model. The process of determining the degree of influence of model parameters on the result output (in our case, temperature) is called sensitivity analysis.

\section{Unresolved questions}

Therefore, the purpose of this work is to study the accuracy influence of model parameters setting on the fire resistance degree values of both protected and unprotected hollow-core floors during their calculated determination using modern software complexes.

There are 2 approaches in setting the parameters when simulating the thermal state and fire resistance of both protected and unprotected hollow-core floors: 1) setting the parameters from regulatory documents (DBN, DSTU, Eurocodes and other reference literature); 2) setting the parameters determined from the fire tests of building structures (solving inverse and direct thermal conductivity problems) [11, 12]. Both these approaches are widely used in the practice of calculating stationary and non-stationary heating of hollow-core floors when designing, reconstructing, constructing new facilities, including the construction of mines in the mining industry.

However, the value of the fire resistance degree of hollow-core floor slabs, determined with the use of such approaches differ, and this causes anxiety. After all, inaccuracy in setting or using such parameters can lead to failure values in determining the fire resistance degree of the studied structures, that will negatively affect the main fire statistics indices (death and injury of people in fires, the number of fires, the number of destroyed and damaged buildings, including mines).

Thus, in work [13], a model has been developed that assesses the probability of the bearing capacity loss of a building structure as a result of a fire that covers buildings of the 
appropriate category. But already in work [14], a subjective assessment is described of the probability of bearing capacity loss of the whole building in the conditions of fire. In [15], the most important conclusions are described from studies conducted in this area in recent years, and a possible method is represented for calculating the bearing capacity of elements of this type with account of heating at variable temperatures in the element. In works [16 18], there are studied the fire safety issues of both separate structures and buildings as a whole without paying attention to the correct choice or setting the parameters for simulating the thermal state and fire resistance of both the building or structure as a whole, and its individual structure or structure element.

Therefore, the study of issues relating to the accuracy and correctness of setting the parameters of the thermal state model of both protected and unprotected hollow-core floors is an actual scientific and technical problem, the solution of which will make possible to more accurately analyze the thermal state of such structures when calculating their fire resistance degree.

\section{Calculated and experimental determination of heating the armoured concrete floor}

When using the first approach in setting the thermal state parameters of hollow-core floors, the procedures described below should be involved.

A physical model should be constructed of the processes occurring in the object during full-scale fire tests. It is proposed to apply the following developed model. When heating from the bottom (Fig. 2), the heat by means of thermal conductivity through the lower concrete layer over the entire floor area and reaches the voids, heating first their lower part. Then, by means of the same thermal conductivity mechanism, the concrete lintels on the sides of the voids are heated from below upwards (with a significantly smaller variable area of lintels), and then again the upper unheated concrete layer over the entire area of the floor. In parallel with the heat transfer by thermal conductivity along the lintels through the cavities, heat is transferred by free convection of air and by radiation from the lower more heated to the upper colder cylindrical walls of the cavities.

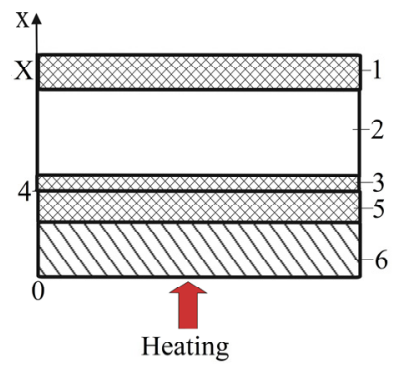

Fig. 2. Physical model of armoured concrete floor in a one-dimensional formulation: 1 - a continuous concrete layer of the floor between the surface, which is being unheated, and a layer with cavities, 2 a layer with cavities, 3 - a continuous concrete layer between the cavities and reinforcement, 4 - a layer of reinforcement, 5 - a continuous concrete layer from the reinforcement to the surface, which is being heated, 6 - plaster covering.

The temperature of the fire medium is set by the standard temperature curve according to the formula (1) and Fig. 3:

$$
T=T_{0}+345 \cdot \lg (8 \tau+1),
$$

where $\tau=180 \mathrm{~min}$ - duration of a fire in minutes; $T_{0}=20{ }^{\circ} \mathrm{C}$ - initial temperature. 


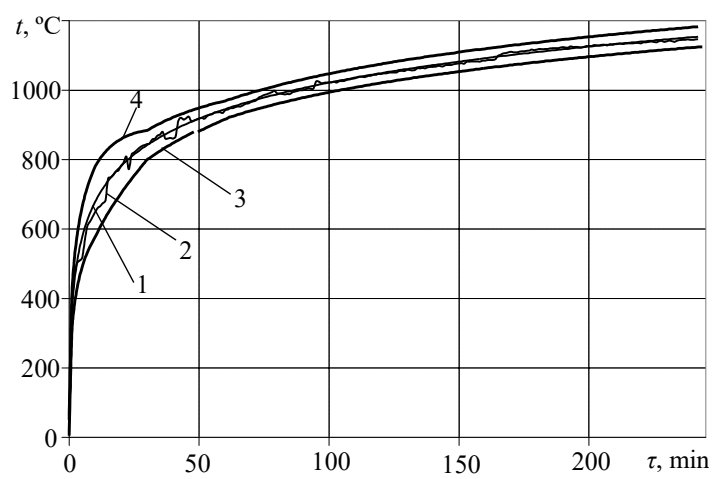

Fig. 3. Dependence of temperature in the furnace from the time of fire exposure on the hollow-core slab surface which is being heated: curve $1-$ a curve of the standard temperature regime; curve $2-a$ real curve of the temperature variation in the furnace; 3 - permissible minimum temperature values in the furnace during testing; 4 - permissible maximum temperature values in the furnace during testing.

The heat-exchange coefficient (2) takes into account the action of convection and radiation. At a simplified approach, the heat-exchange coefficient is equal:

$$
\alpha=\alpha_{P}+\alpha_{K}
$$

where $\alpha_{P}$ is coefficient of heat-exchange by radiation.

The convective and radiation components can be determined from the expressions:

$\alpha_{K}=25 \mathrm{~W} /\left(\mathrm{m}^{2} \cdot \mathrm{K}\right)$ - surface is being heated;

$\alpha_{K}=6 \mathrm{~W} /\left(\mathrm{m}^{2} \cdot \mathrm{K}\right)$ - surface is being unheated.

$$
\alpha_{P}=\varepsilon \cdot \sigma \frac{T_{W}^{4}-T_{P}^{4}}{T_{W}-T_{P}},
$$

where $\varepsilon=0.67$ is degree of the concrete surface blackness (according to A.I. Yakovlev $[19]) ; \sigma=5.67 \cdot 10^{-8} \mathrm{~W} /\left(\mathrm{m}^{2} \cdot \mathrm{K}\right)$ - Stefan-Boltzmann constant; $T_{W}$ is surface temperature, $T_{P}$ is temperature of fire medium.

It was set according Eurocode:

- Poisson's ratio of concrete was accepted to be $v=0.2$;

- concrete consistency $\rho_{0}=2.355 \mathrm{~kg} / \mathrm{m}^{3}$;

- modulus of elasticity of concrete $E_{b}=31.500 \mathrm{MPa}$;

- concrete durability $R_{b}=19.5 \mathrm{MPa}$.

Heat capacity of concrete (Fig. 4):

$c_{p}(\theta)=900 \mathrm{~J} / \mathrm{kg} \cdot \mathrm{K}$

$c_{p}(\theta)=900+(\theta-100) \mathrm{J} / \mathrm{kg} \cdot \mathrm{K}$

$c_{p}(\theta)=1000+(\theta-200) / 2 \mathrm{~J} / \mathrm{kg} \cdot \mathrm{K}$

$c_{p}(\theta)=1100 \mathrm{~J} / \mathrm{kg} \cdot \mathrm{K}$

where $\theta$ is concrete temperature, ${ }^{\circ} \mathrm{C}$.

Concrete consistency:

$\rho(\theta)=\rho\left(20^{\circ} \mathrm{C}\right)$

$\rho(\theta)=\rho\left(20^{\circ} \mathrm{C}\right) \times(1-0.02(\theta-115) / 85)$

$\rho(\theta)=\rho\left(20^{\circ} \mathrm{C}\right) \times(0.98-0.03(\theta-200) / 200)$

$\rho(\theta)=\rho\left(20^{\circ} \mathrm{C}\right) \times(0.95-0.07(\theta-400) / 800)$

Thermal conductivity of concrete (Fig. 5):

$\lambda_{c}=2-0.2451(\theta / 100)+0.0107(\theta / 100)^{2}$ $20^{\circ} \mathrm{C} \leq \theta \leq 100^{\circ} \mathrm{C}$

for $100^{\circ} \mathrm{C}<\theta \leq 200^{\circ} \mathrm{C}$

for $200^{\circ} \mathrm{C}<\theta \leq 400^{\circ} \mathrm{C}$

for $400{ }^{\circ} \mathrm{C}<\theta \leq 1200{ }^{\circ} \mathrm{C}$

for $20^{\circ} \mathrm{C} \leq \theta \leq 115^{\circ} \mathrm{C}$

for $115^{\circ} \mathrm{C}<\theta \leq 200^{\circ} \mathrm{C}$

for $200^{\circ} \mathrm{C}<\theta \leq 400^{\circ} \mathrm{C}$

for $400{ }^{\circ} \mathrm{C}<\theta \leq 1200{ }^{\circ} \mathrm{C}$

for $20^{\circ} \mathrm{C} \leq \theta \leq 1200{ }^{\circ} \mathrm{C}, \mathrm{W} / \mathrm{m} \cdot \mathrm{K}$ 


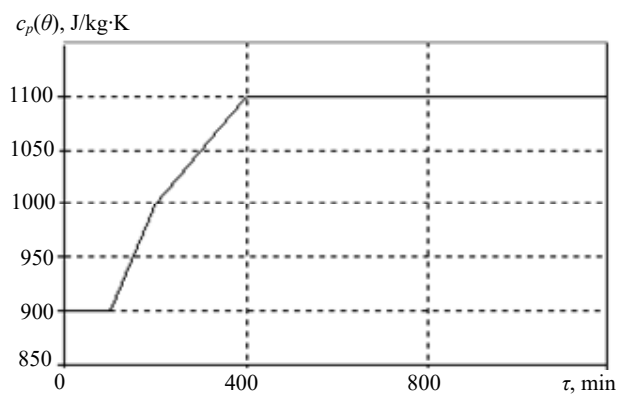

Fig. 4. Dependence of heat capacity on temperature for concrete.

Thermal expansion of concrete (Fig. 6):

$$
\begin{aligned}
& \varepsilon_{c}(\theta)=-1.8 \cdot 10^{-4}+9 \cdot 10^{-6} \theta+2.3 \cdot 10^{-11} \theta^{3} \\
& \varepsilon_{c}(\theta)=14 \cdot 10^{-3}
\end{aligned}
$$

Thermal conductivity of steel (Fig. 7):

$$
\begin{aligned}
& \lambda=54-3.33 \cdot 10^{-2} \theta \\
& \lambda=27.3
\end{aligned}
$$

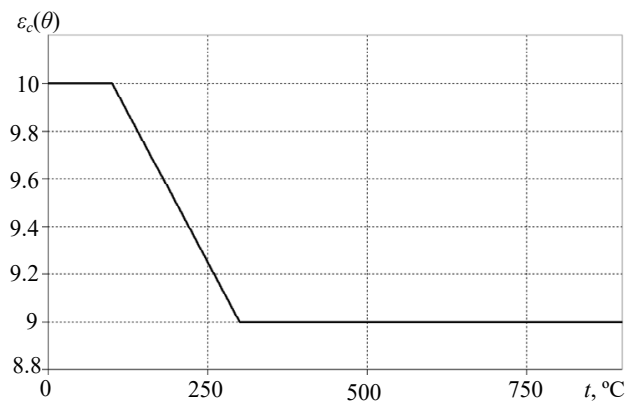

Fig. 6. Dependence of the thermal linear expansion coefficient on the temperature for concrete.

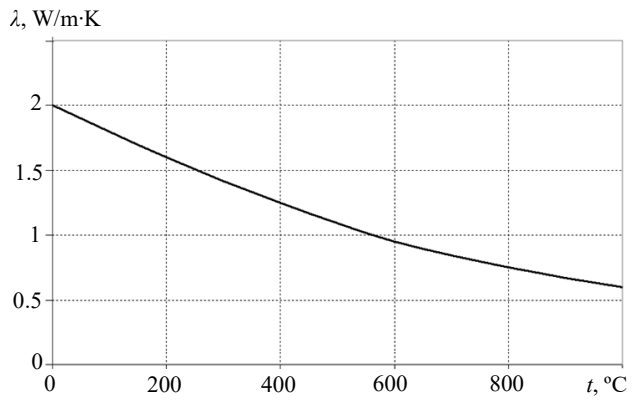

Fig. 5. Dependence of thermal conductivity coefficient on temperature for concrete. for $20{ }^{\circ} \mathrm{C} \leq \theta \leq 800{ }^{\circ} \mathrm{C}$

for $800{ }^{\circ} \mathrm{C} \leq \theta \leq 1200^{\circ} \mathrm{C}$

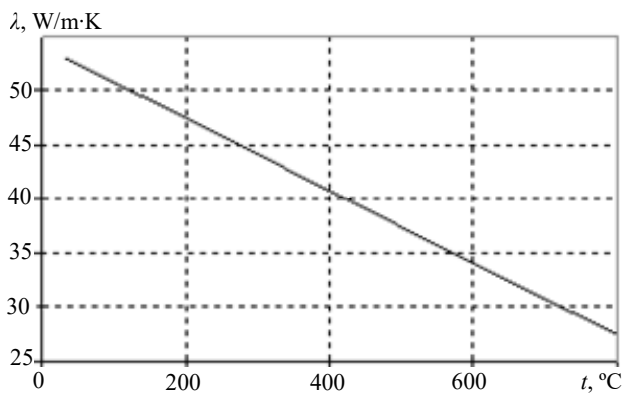

Fig. 7. Dependence of thermal conductivity coefficient on temperature for steel.

Based on the above data using the computer simulation in software complex ANSYS R17.1, a calculation has been performed of non-stationary thermal heating of a hollow-core floor slab, the results of which are represented in Fig. 8 [20 - 22].

To assess the computer simulation results of the thermal state of a concrete floor slab at temperatures corresponding to a fire, the experimental studies have been conducted with subsequent results comparison in the control points of measuring the temperature $[23,24]$.

According to the second approach, a computational-experimental method was used in the assessment of the fire resistance degree of reinforced concrete structures (hollow-core floor slabs), which is a combination of experimental and computational procedures for determining the necessary characteristics of the studied object (Fig. 8), including the dependence of fireretardant coating thickness on the thickness of the protective concrete layer.

To implement this approach, a hollow-core floor slab (prestressed, without use of formwork) PB 36-12-8 (3a) was chosen as the object of study.

The fire resistance degree was determined according to [11] and consisted in heating the slabs samples, installed horizontally into the orifice of a fired furnace under conditions of the standard temperature of a fire, as well as in determining the time when one of the fire 
resistance limit state is reached based on signs of loss of bearing capacity, integrity or thermal insulating capacity. In our case, to determine the fire resistance degree of armoured concrete floors, the criterion was used for the loss of thermal insulating capacity by measuring the temperature on the structure surface which is being unheated.

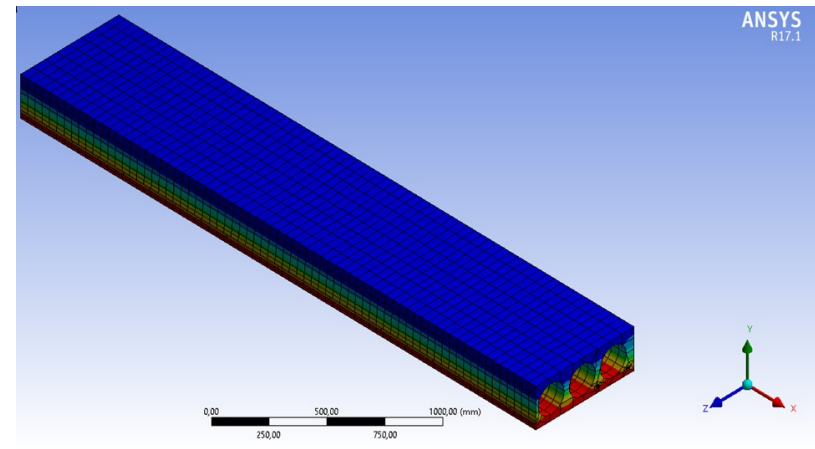

Fig. 8. Temperature distribution in the slab.

Two hollow-core floor slabs were chosen for testing: PB 36-12-8 with $3580 \times 1195 \times 220 \mathrm{~mm}$ in size. The slabs were made without use of formwork and with prestressed reinforcement. The bearing reinforcing cage consisted of four upper longitudinal prestressed reinforcing bars of reinforcing wire Ø5 Bp II and seven lower groups of three reinforcing bars $\varnothing 5 \mathrm{Bp}$ II. The distribution reinforcement was of A240C class with a diameter of $10 \mathrm{~mm}$. The thickness of the protective concrete layer to the axis of the lower reinforcement was $20 \mathrm{~mm}$. A concrete of C25/30 class was used. The specific distributed load according to the order (without its own weight and short-term temporary loads) is $5.54 \mathrm{kPa}$.

The slab samples were mounted on a horizontal furnace with a support by $150 \mathrm{~mm}$ along the edges through a layer of STROPROCK basalt slabs with $40 \mathrm{~mm}$ thick and consistency $160 \mathrm{~kg} / \mathrm{m}^{3}$, produced by Rockwool Polska Sp.z o.o (Fig. 9).

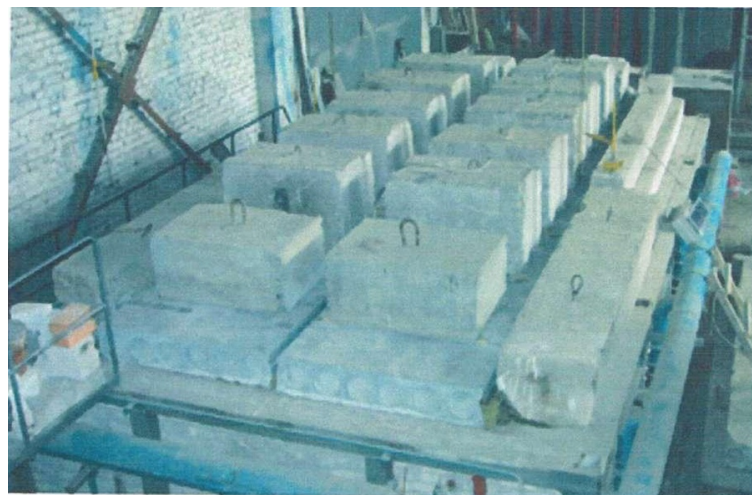

Fig. 9. Overall view of the floor slab samples before testing.

The load was made by calibrated loads in the form of concrete blocks, which were set on the samples through compensating supports $160 \times 30 \times 25 \mathrm{~mm}$ of STROPROCK mineral boards. The actual load on the samples was set based on the creation in the slabs of stresses corresponding to the stresses from the specific distributed load of $5.54 \mathrm{kPa}$ (Fig. 10).

According to the formulas, the maximum deflection values and the rate of increase in deformations were $(45 \mathrm{~min}$ ), $30 \mathrm{~mm}$ and $1 \mathrm{~mm} / \mathrm{min}$ (Sample No. 1) and $31 \mathrm{~mm}$ and 
$1 \mathrm{~mm} / \mathrm{min}$. (Sample No. 2), respectively.

The deflection of the samples was determined by the center of the slabs.
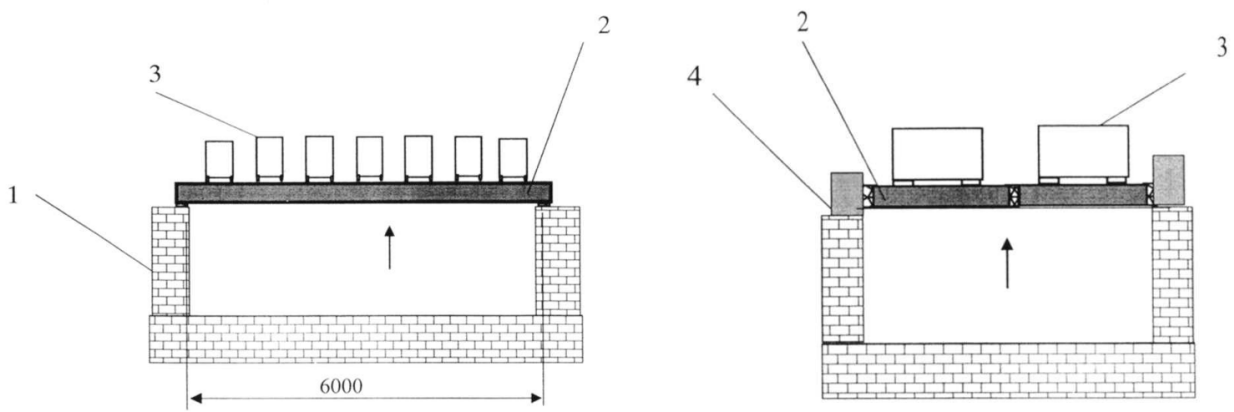

Fig. 10. Scheme of load and support of samples: 1 - a fired furnace; 2 - slab samples; 3 - load blocks; 4 - fencing.

To measure the mean and maximum temperature of each sample surface which is being unheated, 5 thermocouples (T1-T5) were set, one thermocouple (T1) in the center of the sample and four in the geometric centers of the sample quarters (Fig. 11) [23, 24].
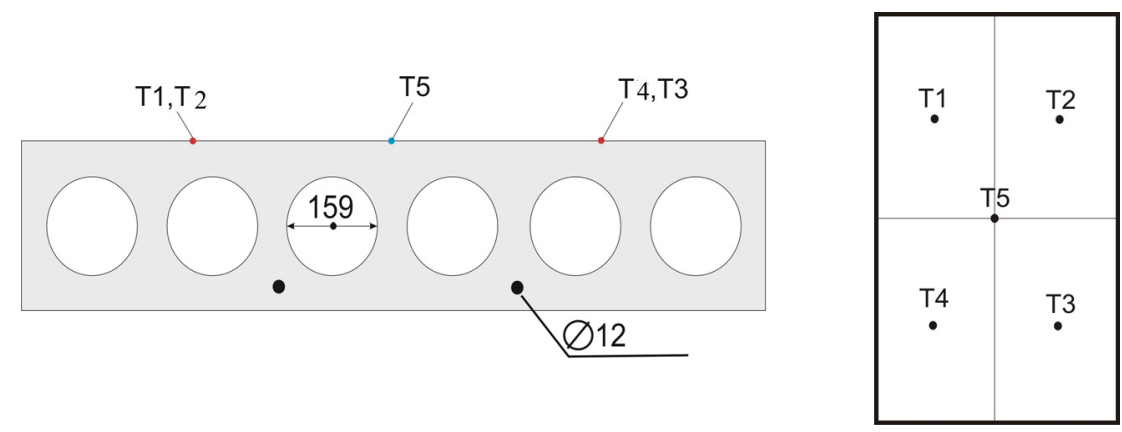

Fig. 11. Scheme of $\mathrm{Cr}-\mathrm{Al}$ thermocouples arrangement from the hollow-core floor surface which is being unheated.

The data obtained as a result of the fire tests, that is, the temperature values in the furnace and from the floor surface which is being unheated, were used further to simulate the entire structure thermal state.

The use of the second approach in setting the parameters of the thermal state of a hollow-core floor provides for the implementation of the procedures described below.

At the first stage - testing for fire resistance of two floor slabs and obtaining temperature values in the furnace and from the surface which is being unheated. In this case, an interesting choice arises for the design engineer: the results of which of the two slabs should be accepted as initial for the beginning the thermal calculations in the appropriate software (such as ANSYS). In fact, two slabs are exposed to testing. If to apply a conservative approach, it is required to choose the values obtained for the slab, which is more heated while testing. It is possible to accept the average values from the test results of 2 slabs - this is also an interesting approach. Then, using the obtained temperature values, by solving inverse thermal conductivity problems, find the thermal and physical concrete characteristics $(\mathrm{TPhC})$, which will be more exact than those specified as averaged in Eurocode. 
It is necessary to describe more specifically, which values of the thermal conductivity coefficient and specific volumetric heat capacity were accepted in the points of measuring the temperature (there is a graph of dependence of the thermal conductivity coefficient and specific volumetric heat capacity on temperature).

According to the authors, it is more correct and advisable to find these TPhCs of concrete by solving inverse thermal conductivity problems according to the results of fire tests of two floor slabs.

It is also necessary to clearly define what fire resistance limit state should be chosen in our study: according to thermal insulating capacity, that is, reaching by a temperature of $160^{\circ} \mathrm{C}$ from the slab surface which is being unheated or when the reinforcement reaches a critical temperature value at a level of load specified in the test (for example, $500{ }^{\circ} \mathrm{C}$ or another temperature in the range of $350-750^{\circ} \mathrm{C}$ ).

As a result of the fire tests, the temperature dependences have been determined in the control points of measuring from the hollow-core slabs surface which is being unheated on the time of fire exposure under conditions of the standard temperature regime of a fire (see Table 1).

The temperature values obtained by simulation (see Fig. 8) were compared with the experimental values obtained during testing the armoured concrete floor for fire resistance under conditions of the standard temperature regime of a fire (Fig. 12).

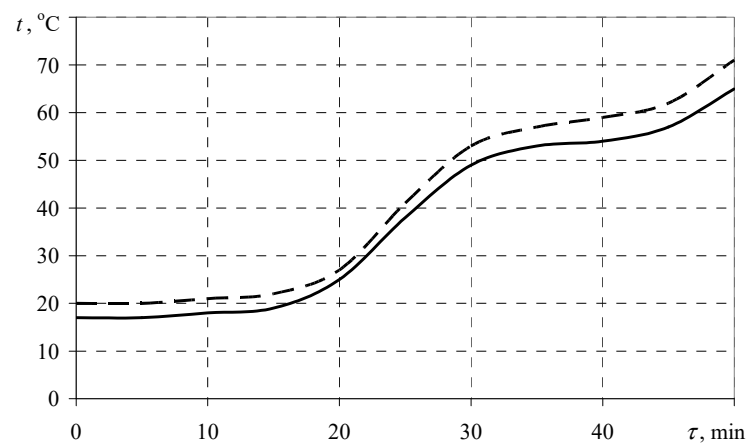

Fig. 12. Dependence of temperature on the time of fire exposure on the hollow-core floor surface which is being unheated in different places of measuing the temperature: dashed-line curve - when simulating in a software complex ANSYS R17.1; solid-line curve - the temperature values, determined during the fire test.

As it can be seen from Fig. 11, the results of experimental studies and numerical analysis in the ANSYS software complex (see Fig. 7) for the first 15 minutes are significantly different in all control points, but later this difference stabilizes and does not exceed $10 \%$ until the end of the experiment, which can be considered acceptable.

It has been studied the thermal state and fire resistance of hollow-core floor using the fire tests and the calculated determination of the fire resistance degree of a structure based on a two-dimensional model of thermal conductivity and convective heat transfer implemented in the ANSYS R17.1 software complex. The fire test of hollow-core floor has been analysed and the use of a computational-experimental method is proposed to determine the parameters when simulating the thermal state and the fire resistance of both protected and unprotected hollow-core floors. A technique has been developed for simulating the thermal state and the fire resistance of hollow-core floors, which can be used in assessing the fire resistance degree of reinforced concrete building structures both in industrial construction and in the mining industry. 


\section{Conclusions}

The statistical data of the fire and technogenic safety in Ukrainian mines have been studied. Recently in Ukraine, there have been frequent cases of collapse, destruction of buildings and structures, including in the mining industry, which indicates the relevance of the scientific research direction, that is, designing the building structures for the explosion action and high temperatures affect during a fire.

A literary analysis has been made of advanced expertise, which is most common in the mining industry, of determining the fire resistance of building structures. As a result of the scientific research, a technique has been proposed for simulating the thermal state and the fire resistance of hollow-core floors, widely used in building and structures of the mining industry.

A technique has been developed and designed that can increase the technogenic and fire safety of buildings and structures in the mining industry. The technique consists of the following stages:

- fire testing and obtaining the dependence of the temperature in the furnace and from the unheated surface on the time of fire exposure according to the standard temperature regime;

- determining the thermal and physical concrete characteristics (TPhC) by solving inverse thermal conductivity problems and comparing how they differ from the thermal and physical characteristics, taken from Eurocode;

- development of a physical model of a hollow-core floor thermal state with division of a slab into 6 layers [22], using a mathematical model [22] with the determined thermal and physical concrete characteristics, performing a calculation of non-stationary heating of armoured concrete floor. The dependences obtained should be compared with the fire test data and calculations in ANSYS;

- determining an error during the calculation and drawing up a conclusion on the accuracy of setting the thermal and physical concrete characteristics, as well as their influence on the determination of the fire resistance degree by means of a computational method.

Authors express their gratitude to P.H. Krukovskyi, Doctor of Technical Sciences, Professor for the help and consultations in performing this work.

\section{References}

1. Tiutiunyk, V.V. Ivanets, H.V., Tolkunov, I.A., \& Stetsyuk, E.I. (2018). System approach for readiness assessment units of civil defense to actions at emergency situations. Naukovyi Visnyk Natsionalnoho Hirnychoho Universytetu, (1), 99-105. https://doi.org/10.29202/nvngu/2018-1/7

2. Vasiliev, M.I., Movchan, I.O., \& Koval, O.M. (2014). Diminishing of ecological risk via optimization of fire-extinguishing system projects in timber-yards. Naukovyi Visnyk Natsionalnoho Hirnychoho Universytetu, (5), 106-113.

3. Vambol, S., Vambol, V., Kondratenko, O., Suchikova, Y., \& Hurenko, O (2017). Assessment of improvement of ecological safety of power plants by arranging the system of pollutant neutralization. Eastern-European Journal of Enterprise Technologies, 3(10-87), 63-73. https://doi.org/10.15587/1729-4061.2017.102314

4. Rybalova, O., \& Artemiev, S. (2017). Development of a procedure for assessing the environmental risk of the surface water status deterioration. Eastern-European Journal of Enterprise Technologies, 5(10-89), 67-76. https://doi.org/10.15587/1729-4061.2017.112211

5. Semko, A.N., Beskrovnaya, M.V., Vinogradov, S.A., Hritsina, I.N., \& Yagudina, N.I. (2014). The usage of high speed impulse liquid jets for putting out gas blowouts. Journal of Theoretical and Applied Mechanics, 52(3), 655-664. 
6. Andronov, V.A., Danchenko, Yu.M., Skripinets, A.V., Bukhman, O.M. (2014). Efficiency of utilization of vibration-absorbing polimer coating for reducing local vibration Terms and conditions Privacy policy. Naukovyi Visnyk Natsionalnoho Hirnychoho Universytetu, (6), 85-91.

7. Dubinin, D., Korytchenko, K., Lisnyak, A., Hrytsyna, I., \& Trigub, V. (2017). Numerical simulation of the creation of a fire fighting barrier using an explosion of a combustible charge. Eastern-European Journal of Enterprise Technologies, 6(10-90), 11-16. https://doi.org/10.15587/1729-4061.2017.114504

8. Bondarenko, V., Kovalevs'ka, I., Ganushevych, K. (2014). Progressive Technologies of Coal, Coalbed Methane, and Ores Mining. https://doi.org/10.1201/b17547

9. Bondarenko, V., Kovalevs'ka, I., \& Fomychov, V. (2012). Features of carrying out experiment using finite-element method at multivariate calculation of "mine massif - Combined support" system. Geomechanical Processes during Underground Mining: School of Underground Mining 2012, 7-13. https://doi.org/10.1201/b13157-3

10. Kovalevs'ka, I., Symanovych, G., \& Fomychov, V. (2013). Research of stress-strain state of cracked coal-containing massif near-the-working area using finite elements technique. Annual Scientific-Technical Collection - Mining of Mineral Deposits 2013, 159-163. https://doi.org/10.1201/b16354-28

11. DSTU B V.1.1-4-98. (1999). Zakhyst vid pozhezhi. Budivelni konstruktsii. Metody vyprobuvannia na vohnestiikist. Zahalni vymohy. Kyiv: Ukrarkhbudinform.

12. Korneeva, S. \& Neutov, M. (2017). Suriyaninov, Experimental studies of fiber concrete creep, MATEC Web of Conferences, (116), 02021. https://doi.org/10.1051/matecconf/201711602021

13. Garlińska, U., Michalak, P., \& Popielarczyk, T. (2015). Szacowanie możliwości utraty nośności konstrukcji budowlanej w warunkach pożaru. Bezpieczeństwo i Technika Pożarnicza 2015, 39(3), 59-66. https://doi.org/10.12845/bitp.39.3.2015.5

14. Garlińska, U., Michalak, P., \& Popielarczyk, T. (2016). Subiektywna ocena możliwości utraty nośności konstrukcji budowlanej w warunkach pożaru. Bezpieczeństwo i Technika Pożarnicza 2015, 43(3), 37-44. https://doi.org/10.12845/bitp.43.3.2016.3

15. Biskupska, N., \& Szymkuć, W. (2016). Towards the simplified modelling of thermal and mechanical response of steel tubular columns exposed to localized fire. In 12th International Conference "Modern Building Materials, Structures and Techniques". Artykuł przyjęty do publikacji w "Procedia Engineering".

16. Obiala, R., Vassart, O., Zhao, B., Sakji, M.S, de la Quintana J., Morente, F., Franssen, J.-M., \& Lansival, J.-B. (2010). Fire safety of industrial halls - A valorisation project. Research Fund for Coal and Steel. Final report RFS2-CT-2007-00032.

17. Lange, D., \& Sjostrom, J. (2014). Mechanical response of a partially restrained column exposed to localised fires. Fire Safety Journal, (67), 82-95.

18. Correia, A.J.P.M., \& Rodrigues, J.P.C., Vila Real, P. (2014). Thermal bowing on steel columns embedded on walls under fire conditions. Fire Safety Journal, (67), 53-69.

19. Yakovlev, A.I. (1988). Raschet ognestoykosti stroitel'nykh konstrukciy. Moskva: Stroyizdat.

20. Surianinov, M., \& Shyliaiev, O. (2018). Calculation of plate-beam systems by method of boundary elements. International Journal of Engineering and Technology (UAE), 7(2), 238-241. https://doi.org/10.14419/ijet.v7i2.23.11927

21. Dashhenko, A.F., Lazareva, D.V., Sur'yaninov, N.G. (2011). ANSYS v zadachakh inzhenernoy mekhaniki. Odesa.

22. Otrosh, Y., Kovalov, A., Semkiv, O., Rudeshko, I., \& Diven, V. (2018). Methodology remaining lifetime determination of the building structures. MATEC Web of Conferences, (230), 02023. https://doi.org/10.1051/matecconf/201823002023 T

23. Andronov, V., Pospelov, B., \& Rybka, E. (2016). Increase of accuracy of definition of temperature by sensors of fire alarms in real conditions of fire on objects. Eastern-European Journal of Enterprise Technologies, 4(5-82), 38-44. https://doi.org/10.15587/1729$\underline{4061.2016 .75063}$ 
24. Andronov, V., Pospelov B., Rybka, E., \& Skliarov, S. (2017). Examining the learning fire detectors under real conditions of application. Eastern-European Journal of Enterprise Technologies, 3(9-87), 53-59. https://doi.org/10.15587/1729-4061.2017.101985

25. Kovalov, A., Otrosh, Y., Ostroverkh, O., Hrushovinchuk, O., Savchenko, O. (2018). Fire resistance evaluation of reinforced concrete floors with fire-retardant coating by calculation and experimental method. E3S Web of Conferences, (60), 00003. https://doi.org/10.1051/e3sconf/20186000003 